UDC 614.7

DOI: $10.21668 /$ health.risk/2019.3.02.eng

\title{
POPULATION HEALTH RISK CAUSED BY EXPOSURE TO CHEMICALS IN SOILS
}

\author{
A.N. Deryabin ${ }^{1,2}$, T.N. Unguryanu ${ }^{1,2}$, R.V. Buzinov ${ }^{1,2}$ \\ ${ }^{1}$ Federal Service for Surveillance over Consumer Rights Protection and Human Wellbeing, Arkhangelsk Region \\ office, 24 Gaidara Str., Arkhangelsk, 163000, Russian Federation \\ ${ }^{2}$ Northern State Medical University, 51 Troitskiy Ave., Arkhangelsk, 163000, Russian Federation
}

Our research goal was to comparatively analyze soils contamination with chemicals in cities located in the Arctic zone of Arkhangelsk region and to assess population health risk caused by soils in settlements contaminated with chemicals. The research has practical significance due to Arkhangelsk region being among the RF regions with the highest share of soils samples taken in settlements that deviate from hygienic standards as per sanitary-chemical and microbiological parameters.

The assessment was based on monitoring data on chemical contamination of soils in cities located in the Arctic zone of Arkhangelsk region (Severodvinsk, Arkhangelsk, and Novodvinsk) collected in 2007-2017. We assessed population exposure to contaminants in soils at their oral and subcutaneous introduction and determined risk levels for children's and adults' health. To examine non-carcinogenic effects, we applied reference doses and calculated hazard coefficients and indexes. We revealed that soils were contaminated with metals substantially greater in Severodvinsk than in two other cities. Aggregated hazard indexes calculated for combined introduction of contaminants from soils didn't exceed 1.0. Contaminants from soils primarily enter a body via oral introduction. A contribution made by oral introduction into a total dose for examined toxicants amounted to 68-79\% at the median level among children and adults. Overall individual carcinogenic risk in Severodvinsk was higher than in two other cities and amounted to $9.1 \cdot 10^{-4}$ and $2.3 \cdot 10^{-3}$ at the median level and 90\%-percentile one accordingly. Non-carcinogenic and carcinogenic risks caused by exposure to contaminants in soils are acceptable when taken in their median concentrations.

Key words: soil contamination, chemicals, soils in settlements, deviation from hygienic standards, risk assessment, risk level.

Soil is a most significant component in the environment; it accumulates chemicals and causes secondary contamination of ambient air and water [1, 2]. Chemicals occur in soil mostly due to discharges and emissions from industrial enterprises, motor transport, communal and industrial wastes [3-7].

Chemical contaminants in soil can exert their influence on population health both via direct contacts with soils (handworks with soils, walking barefoot, children playing in sandboxes etc.) and via chemicals penetrating a body indirectly via media that contact soils (ambient air or water) [3, 8]. Heavy metals are the most hazardous toxicants for human health [9-11] as they produce toxic, allergenic, carcinogenic, and mutagenic effects [12, 13]. Copper, zinc, nickel, lead, and cadmium are among priority chemical soil contaminants $[3,14-16]$.

Arkhangelsk region is one of RF regions with the highest share of soil samples taken in settlements that deviate from hygienic standards as per sanitary-chemical and microbi-

(C) Deryabin A.N., Unguryanu T.N., Buzinov R.V., 2019

Aleksey N. Deryabin - Chief Expert at the Sanitary Surveillance Department; a post-graduate student (e-mail: deryabinan@mail.ru; tel.: +7 (8182) 65-27-93; ORCID: https://orcid.org/0000-0002-1853-8947).

Tatiana N. Unguryanu - Doctor of Medical Sciences, Associate professor, Chief Expert at the Organization and Maintenance Department; Professor at the Department for Hygiene and Medical Ecology (e-mail: unguryanu_tn@mail.ru; tel.: +7(8182) 21-04-61; ORCID: https://orcid.org/0000-0001-8936-7324).

Roman V. Buzinov - Doctor of Medical Sciences, Associate professor, Supervisor; Professor at the Department for Hygiene and Medical Ecology (e-mail: arkh@29.rospotrebnadzor.ru; tel.: +7(8182) 20-05-69; ORCID: https:// orcid.org/0000-0002-8624-6452). 
ological parameters. In 2015-2017 a specific share of soils samples taken in settlements in the region that didn't conform to hygienic standards as per sanitary-chemical parameters amounted to $6.5 \%$ and it was 1.3 times higher than on average in the country $(5.1 \%)^{1,2}$.

The present research was performed in three big industrial cities in Arkhangelsk region (Arkhangelsk, Severodvinsk, and Novodvinsk) located in arctic zones ${ }^{3}$, namely in the northern taiga sub-zone. Arctic air makes for cold and dry weather on these territories. Average temperature in January is $-14.7^{\circ} \mathrm{C}$; in July, $+14.8^{\circ} \mathrm{C}$ [17]. Cold climate, little precipitation, and short growing season result in metals accumulation in soils [18]. Given that, it is vital to examine soil contamination with chemicals in cities located in arctic zones and impacts exerted by it on population health.

Our research goal was to comparatively analyze soil contamination with chemicals in cities located in arctic zones of Arkhangelsk region and assess population health risks caused by exposure to contaminants in soils.

Data and methods. We performed a descriptive examination of soil quality in Arkhangelsk, Severodvinsk, and Novodvinsk. Emissions from industrial enterprises were analyzed as per data collected over 2010-2015 and taken from statistic reports "2-TP Air". Soil contamination with chemicals was examined as per monitoring data collected over 2007-2017 and provided by the Center for Hygiene and Epidemiology in Arkhangelsk region. We assessed population health risks caused by exposure to chemical contaminants in soils for 10 metals: copper $(\mathrm{Cu})$, chromium
$(\mathrm{Cr})$, zinc $(\mathrm{Zn})$, nickel $(\mathrm{Ni})$, manganese $(\mathrm{Mn})$, lead $(\mathrm{Pb})$, mercury $(\mathrm{Hg})$, cadmium $(\mathrm{Cd})$, cobalt (Co), and arsenic (As). All soil samples were taken in settlements, near housing, and at children playgrounds and sport grounds.

We used median (Me) and 90-th percentile $\left(\mathrm{P}_{90}\right)$ to describe concentrations of the examined chemicals in soils and to calculate risk levels. Since distribution of chemicals concentrations statistically significantly differed from normal one, we applied Kruskal-Wallis test to compare median values and Wilcoxon twosample test to make pairwise comparison between groups. Critical level of statistical significance was taken as equal to 0.05 . We used growth rate to examine dynamics of chemicals concentrations in soils. Statistical analysis was performed with STATA 14.0.

We studied overall toxic and carcinogenic effects produced by soil contaminants on population health according to overall principles of risk assessment methodology 4 . We took the following regional values for exposure factors: body mass $(\mathrm{kg})$, duration of exposure (days per year), time spent in the open air (hours per day), duration of a contact with soil (hours per day) [19]. We assessed exposure to soil contaminants for oral and subcutaneous introduction. Risk levels were determined separately for children (age groups were 1-6 and 7-17), and adults 5,6 .

We applied reference doses to examine non-carcinogenic effects. Toxicity of contaminants was characterized basing on chronic daily introduction of a substance $(\mathrm{mg} / \mathrm{kg}$ of body mass), hazard quotients (HQ) for specific contaminants and total hazard quotients (THQ)

\footnotetext{
${ }^{1}$ On sanitary-epidemiologic welfare of the population in Russia in 2017: State report. Moscow, Federal Service for Surveillance over Consumer Rights Protection and Human Well-being Publ., 2018, 268 p.

${ }^{2}$ On sanitary-epidemiologic welfare of the population in in Arkhangelsk region in 2017: State report. Arkhangelsk, Federal Service for Surveillance over Consumer Rights Protection and Human Well-being, Arkhangelsk regional office Publ., 2018,149 p.

${ }^{3}$ Land territories in the RF Arctic zones: The RF President Order no. 296 dated May 02, 2014. KonsultantPlus. Available at: http://www.consultant.ru/document/cons doc LAW_162553/(date of visit December 10, 2018).

${ }^{4} \mathrm{P}$ 2.1.10.1920-04. Guide on assessing population health risks under exposure to chemicals that pollute the environment. Moscow, The Federal Center for State Sanitary and Epidemiologic Surveillance of RF Public Healthcare Ministry, 2004,143 p.

${ }^{5}$ Public Health Assessment Guidance Manual (Update). Atlanta, U.S. Department of Health and Human Services Public Health Service Agency for Toxic Substances and Disease Registry, 2005. Available at: http://www.atsdr.cdc.gov/ hac/phamanual/pdfs/phagm_final1-27-05.pdf (date of visit December 10, 2018).

${ }^{6}$ Supplemental guidance for developing soil screening levels for superfund sites. Washington DC: Office of Emergency and Remedial Response U.S. EPA, 2002. Available at: https://www.epa.gov/superfund/superfund-soil-screening-guidance (date of visit December 10, 2018).
} 
for specific contaminants and for all ways of introduction. We calculated hazard indexes (HI) and total hazard indexes (THI) for substances with similar effects as such indexes allowed us to assess how susceptible critical systems and organs were to these effects.

Carcinogenic effects were assessed basing on an average daily dose calculated for a lifetime $(\mathrm{mg} / \mathrm{kg} \times$ day $)$ and slope factor. We calculated the following carcinogenic risks: individual carcinogenic risk (CR) for each separate carcinogen; summary carcinogenic risk $\left(\mathrm{CR}_{\text {sum }}\right)$ for all substances for each way of introduction and for specific carcinogens introduced via all ways; total carcinogenic risk (TCR) for all the substances and ways of introduction and population carcinogenic risk (PCR) taking into account children and adult population in the examined cities.

HQ, HI, and THI values lower than 1.0 were considered to be acceptable; for carcinogenic effects, $\mathrm{CR}$ value within $1.0 \times 10^{-6}$ $1.0 \times 10^{-4}$ according to the Guide ${ }^{4}$.

Results and discussion. Soils are examined at 13 monitoring points within social and hygienic monitoring activities performed in Severodvinsk; at 17 monitoring points in Arkhangelsk; and at 9 monitoring points in Novodvinsk. On January 01, 2018 population in Archangelsk amounted to 356.9 thousand; in Severodvinsk, 184.3 thousand; in Novodvinsk, 38.4 thousand.

Over 2007-2017 23,200 soil samples were examined in all three cities and chemicals concentrations were determined in them; 1,362 samples out of them didn't conform to hygienic standards $(5.9 \%)$. The greatest specific share of samples that deviated from hygienic standards as per contaminants in them was determined in Severodvinsk during that time period $(83 \%)$. A share of soil samples taken in Severodvinsk that didn't conform to hygienic standards as per copper, chromium, zinc, nickel, lead, and arsenic, amounted to $40 \% ; 3,2 \% ; 19,1 \% ; 43 \% ; 25 \%$, and $8 \%$ respectively; as per cadmium and manganese contents, less than $1 \%$. Mercury and cobalt were detected in soils in concentrations conforming to hygienic standards.
Median concentrations of copper, zinc, nickel, and lead didn't exceed MPC in examined soil samples in Severodvinsk, but concentrations of these chemicals were higher than permissible ones at the upper exposure limit. Soil contamination with zinc, nickel, lead, and copper, taken at $\mathrm{P}_{90}$ turned out to be 1.7-4 times higher than MPC. We analyzed long-term dynamics of nickel, zinc, lead, and copper concentrations in soils taken at $\mathrm{P}_{90}$ and revealed that contamination level was growing. From 2007 to 2017 an average growth rate taken at $\mathrm{P}_{90}$ amounted to $2.3 \% ; 24.6 \%$; $25.5 \%$, and $66.3 \%$ respectively. Chromium, manganese, mercury, cadmium, cobalt, and arsenic concentrations in examined soils samples taken both at $\mathrm{Me}$ and $\mathrm{P}_{90}$ didn't deviate from permissible levels.

In Arkhangelsk a share of soil samples that contained zinc and lead in concentrations higher than MPC amounted to $7 \%$ and $6 \%$ respectively. Soil quality as per these two chemicals has deteriorated over the examined period with average growth rate at $\mathrm{P}_{90}$ level being equal to $14.7 \%$ for zinc and $0.4 \%$ for lead. A share of soil samples that contained copper, nickel, and manganese in quantities higher than MPC was lower than $1 \%$. There were no soil samples deviating from hygienic standards as per concentrations of other examined chemicals.

In Novodvinsk the highest specific weight of samples not conforming to hygienic standards was detected for copper, zinc, and lead $(1.3 \% ; 8 \%$, and $1.5 \%$ respectively). We analyzed long-term dynamics as regards concentrations of these chemicals in soils and revealed that contamination tended to increase. An average growth rate over the examined period at $\mathrm{P}_{90}$ level amounted to $41.7 \%$ for copper; $19 \%$, zinc; $4.2 \%$, lead. We didn't detect any soil samples that didn't conform to hygienic standards as per concentrations of chromium, nickel, manganese, mercury, cadmium, and cobalt. Contents of copper, chromium, zinc, nickel, manganese, lead, mercury, cobalt, and cadmium in soils taken at $\mathrm{Me}$ and $\mathrm{P}_{90}$ didn't exceed permissible levels in Arkhangelsk and Novodvinsk. 
We comparatively analyzed contents of contaminants in soils in cities located in arctic zones of Arkhangelsk region; data on contamination taken at median level revealed that soil was statistically significantly more contaminated with metals in Severodvinsk $(\mathrm{p}<0.001)$ than in tow other examined cities. Average concentrations of zinc, lead, cadmium, manganese, and mercury in soil samples taken in Severodvinsk were 5-23 times higher than contents of these metals in soils in Arkhangelsk and 3.-13 times higher than in soil in Novodvinsk. Median cobalt concentration in soil in Severodvinsk was 80 times higher than its contents in Arkhangelsk and Novodvinsk. Median copper, chromium, and nickel concentrations in soil in Severodvinsk were 7, 30, and 47 times higher than in Arkhangelsk and Novodvinsk (Table 1).

Increased metals concentrations in soil in Severodvinsk occur sue to high density of these substances contained in emissions from industrial enterprises and motor transport. Shipbuilding and machine building are the leading industries in Severodvinsk; wood processing and food industry, in Arkhangelsk; pulp and paper production, in Novodvinsk. According to data taken from "2-TP Air" report form, density of manganese, copper, and lead emissions per $1 \mathrm{~km}^{2}$ amounted to $19,3.1$ and $0.08 \mathrm{~kg}$ respectively in Severodvinsk; $0.7,0.06$, and $0.003 \mathrm{~kg}$ respectively, in Arkhangelsk; 1.2, 0.01, and $0.00006 \mathrm{~kg}$ respectively, in Novodvinsk. Zink, nickel, and chromium occurred only in emissions from industrial enterprises in Severodvinsk $(0.68,3.61$, and $0.003 \mathrm{~kg}$ respectively). As per data obtained from The Northern Office for Hydrometeorology and Environmental Monitoring, a contribution made by motor transport into ambient air contamination amounted to $57 \%$ in Arkhangelsk; 24\%, in Severodvinsk; 6\%, in Novodvinsk.

Total hazard quotients for each metal taken as a sum for oral and subcutaneous exposure didn't exceed 1.0 in all the examined cities.

We comparatively analyzed total introduced doses of chemicals that contaminated soils in Cities located in Arkhangelsk-
Severodvinsk agglomeration and revealed that dose burden for children aged 1-6 was 1.6 and 4.8 times higher respectively than doses of chemicals received by children aged 7-17 and by adults. Children aged 7-17 were exposed to 3 times higher doses of chemical toxicants in soil that adult population.

Table 1

Contents of contaminants in soils in cities located in arctic zones of Arkhangelsk region over 2007-2017

\begin{tabular}{|c|c|c|c|c|}
\hline Substance & $\begin{array}{c}\text { Number } \\
\text { of samples }\end{array}$ & $\mathrm{Me}^{*}$ & $\mathrm{P}_{90}$ & $\begin{array}{c}\text { MPC } \\
(\mathrm{mg} / \mathrm{kg})\end{array}$ \\
\hline \multicolumn{5}{|c|}{ Severodvinsk } \\
\hline Copper & 852 & 2.4 & 12.4 & 3.0 \\
\hline Chromium & 533 & 3.0 & 5.8 & 6.0 \\
\hline Zinc & 852 & 10.0 & 38.0 & 23.0 \\
\hline Nickel & 774 & 4.0 & 10.0 & 4.0 \\
\hline Manganese & 764 & 54.0 & 93.0 & 140.0 \\
\hline Lead & 852 & 3.1 & 10.0 & 6.0 \\
\hline Mercury & 852 & 0.05 & 0.25 & 2.1 \\
\hline Cadmium & 852 & 0.1 & 0.1 & $2.0^{* *}$ \\
\hline Cobalt & 764 & 2.0 & 4.0 & 5.0 \\
\hline Arsenic & 813 & 0.8 & 2.0 & 2.0 \\
\hline \multicolumn{5}{|c|}{ Arkhangelsk } \\
\hline Copper & 1109 & 0.3 & 1.01 & 3.0 \\
\hline Chromium & 1107 & 0.1 & 0.1 & 6.0 \\
\hline Zinc & 1109 & 1.9 & 18.4 & 23.0 \\
\hline Nickel & 1109 & 0.09 & 0.6 & 4.0 \\
\hline Manganese & 1109 & 2.8 & 16.2 & 140.0 \\
\hline Lead & 1109 & 0.4 & 4.4 & 6.0 \\
\hline Mercury & 1109 & 0.002 & 0.12 & 2.1 \\
\hline Cadmium & 1107 & 0.008 & 0.06 & $2.0 * *$ \\
\hline Cobalt & 1109 & 0.03 & 0.3 & 5.0 \\
\hline \multicolumn{5}{|c|}{ Novodvinsk } \\
\hline Copper & 594 & 0.3 & 1.1 & 3.0 \\
\hline Chromium & 594 & 0.1 & 0.1 & 6.0 \\
\hline Zinc & 594 & 2.9 & 21.2 & 23.0 \\
\hline Nickel & 594 & 0.09 & 0.4 & 4.0 \\
\hline Manganese & 593 & 4.1 & 16.8 & 140.0 \\
\hline Lead & 594 & 0.5 & 2.2 & 6.0 \\
\hline Mercury & 585 & 0.01 & 0.2 & 2.1 \\
\hline Cadmium & 594 & 0.01 & 0.06 & $2.0^{* *}$ \\
\hline Cobalt & 594 & 0.03 & 0.3 & 5.0 \\
\hline
\end{tabular}

Note:

p* means median values are compared as per Wilcoxon test $(\mathrm{p}<0.001$ for all chemicals);

$* *$ is ODC value for cadmium. 
Oral exposure is a basic one for contaminants in soil. A contribution made by oral exposure into the total dose for the examined toxicants, taken at its median level, on average amounted to $79 \%$ for children aged $1-6 ; 73 \%$, for children aged $7-17$; and $68 \%$, for adults.

Circulatory organs, blood system, central nervous system, and kidneys are organs exposed to the highest risks of overall toxic effects that are produced on population living in arctic zones under exposure to chemi- cal contaminants in soil. The liver, skin, digestive organs, reproductive and immune system occupy the second rank place in terms of exposure. We should note that a risk of non-carcinogenic effects for all the critical organs and systems didn't exceed permissible level $(\mathrm{THI}=1)$ either for children or adults (Table 2). Differences in noncarcinogenic risk levels among children and adults are due to different duration and time of exposure, body mass and body surface area [20].

Table 2

Critical organs and systems ranked as per total hazard quotients (THI) under exposure to complex introduction of chemical contaminants in soils occurring in cities located in Arkhangelsk region

\begin{tabular}{|c|c|c|c|c|c|c|}
\hline \multirow{2}{*}{ Critical organs and systems } & \multicolumn{2}{|c|}{$\begin{array}{c}\text { Children aged } \\
1-6\end{array}$} & \multicolumn{2}{|c|}{$\begin{array}{c}\text { Children aged } \\
7-17\end{array}$} & \multicolumn{2}{|c|}{ Adults } \\
\hline & $\mathrm{P}_{50}$ & $\mathrm{P}_{90}$ & $\mathrm{P}_{50}$ & $\mathrm{P}_{90}$ & $\mathrm{P}_{50}$ & $\mathrm{P}_{90}$ \\
\hline \multicolumn{7}{|c|}{ Severodvinsk } \\
\hline Circulatory organs & 0.035 & 0.064 & 0.025 & 0.045 & 0.009 & 0.016 \\
\hline Blood system & 0.033 & 0.059 & 0.023 & 0.041 & 0.008 & 0.015 \\
\hline Nervous system & 0.023 & 0.041 & 0.017 & 0.030 & 0.006 & 0.011 \\
\hline Kidneys & 0.023 & 0.041 & 0.017 & 0.030 & 0.006 & 0.011 \\
\hline Liver & 0.017 & 0.029 & 0.013 & 0.022 & 0.005 & 0.008 \\
\hline Skin & 0.013 & 0.028 & 0.009 & 0.018 & 0.003 & 0.006 \\
\hline Digestive organs & 0.006 & 0.013 & 0.004 & 0.009 & 0.002 & 0.003 \\
\hline Reproductive system & 0.006 & 0.012 & 0.004 & 0.008 & 0.002 & 0.003 \\
\hline Immune system & 0.003 & 0.009 & 0.002 & 0.007 & 0.001 & 0.003 \\
\hline \multicolumn{7}{|c|}{ Arkhangelsk } \\
\hline Circulatory organs & 0.0015 & 0.011 & 0.001 & 0.008 & 0.0004 & 0.0028 \\
\hline Blood system & 0.0015 & 0.011 & 0.001 & 0.007 & 0.0004 & 0.0027 \\
\hline Nervous system & 0.0014 & 0.011 & 0.001 & 0.008 & 0.0004 & 0.003 \\
\hline Kidneys & 0.0014 & 0.011 & 0.001 & 0.008 & 0.0004 & 0.003 \\
\hline Liver & 0.0009 & 0.005 & 0.0006 & 0.004 & 0.0002 & 0.0014 \\
\hline Digestive organs & 0.0005 & 0.006 & 0.0004 & 0.005 & 0.0001 & 0.0017 \\
\hline Reproductive system & 0.0005 & 0.006 & 0.0004 & 0.004 & 0.0001 & 0.0016 \\
\hline Skin & 0.0002 & 0.002 & 0.0001 & 0.001 & 0.0001 & 0.0004 \\
\hline Immune system & 0.0001 & 0.003 & 0.0001 & 0.002 & 0.00003 & 0.0008 \\
\hline \multicolumn{7}{|c|}{ Novodvinsk } \\
\hline Nervous system & 0.002 & 0.012 & 0.0015 & 0.0089 & 0.0006 & 0.0034 \\
\hline Kidneys & 0.002 & 0.012 & 0.0015 & 0.0089 & 0.0006 & 0.0034 \\
\hline Circulatory organs & 0.002 & 0.0095 & 0.0015 & 0.0068 & 0.0005 & 0.0025 \\
\hline Blood system & 0.002 & 0.0093 & 0.0014 & 0.0067 & 0.0005 & 0.0025 \\
\hline Liver & 0.0012 & 0.005 & 0.0009 & 0.004 & 0.0004 & 0.0015 \\
\hline Digestive organs & 0.0009 & 0.007 & 0.0006 & 0.005 & 0.0002 & 0.002 \\
\hline Reproductive system & 0.0008 & 0.007 & 0.0006 & 0.005 & 0.0002 & 0.0019 \\
\hline Immune system & 0.0003 & 0.004 & 0.0002 & 0.003 & 0.0001 & 0.0013 \\
\hline Skin & 0.0002 & 0.002 & 0.0001 & 0.001 & 0.0001 & 0.0004 \\
\hline
\end{tabular}


Table 3

Individual, total and summary total carcinogenic risks under exposure to soil contaminants in cities located in Arkhangelsk region

\begin{tabular}{|c|c|c|c|c|c|c|}
\hline \multirow{3}{*}{ Carcinogens } & \multicolumn{4}{|c|}{ Introduction } & \multirow{2}{*}{\multicolumn{2}{|c|}{$\mathrm{CR}_{\text {sum }}$}} \\
\hline & \multicolumn{2}{|c|}{ Oral } & \multicolumn{2}{|c|}{ Subcutaneous } & & \\
\hline & $\mathrm{P}_{50}$ & $\mathrm{P}_{90}$ & $\mathrm{P}_{50}$ & $\mathrm{P}_{90}$ & $\mathrm{P}_{50}$ & $\mathrm{P}_{90}$ \\
\hline \multicolumn{7}{|c|}{ Severodvinsk } \\
\hline Nickel & $9.4 \times 10^{-5}$ & $2.4 \times 10^{-4}$ & $7.4 \times 10^{-4}$ & $1.8 \times 10^{-3}$ & $8.3 \times 10^{-4}$ & $2.1 \times 10^{-3}$ \\
\hline Lead & $4.1 \times 10^{-7}$ & $1.3 \times 10^{-6}$ & $1.3 \times 10^{-7}$ & $4.2 \times 10^{-7}$ & $5.4 \times 10^{-7}$ & $1.8 \times 10^{-6}$ \\
\hline Arsenic & $1.9 \times 10^{-5}$ & $4.7 \times 10^{-5}$ & $6.0 \times 10^{-5}$ & $1.5 \times 10^{-4}$ & $7.9 \times 10^{-5}$ & $2.0 \times 10^{-4}$ \\
\hline Cobalt & $6.3 \times 10^{-7}$ & $1.3 \times 10^{-6}$ & $2.0 \times 10^{-7}$ & $3.9 \times 10^{-7}$ & $8.3 \times 10^{-7}$ & $1.7 \times 10^{-6}$ \\
\hline $\mathrm{CR}_{\text {sum }}$ & $1.1 \times 10^{-4}$ & $2.9 \times 10^{-4}$ & $8.0 \times 10^{-4}$ & $2.0 \times 10^{-3}$ & $9.1 \times 10^{-4}$ & $2.3 \times 10^{-3}$ \\
\hline \multicolumn{7}{|c|}{ Arkhangelsk } \\
\hline Nickel & $2.0 \times 10^{-6}$ & $1.3 \times 10^{-5}$ & $1.6 \times 10^{-5}$ & $1.0 \times 10^{-4}$ & $1.8 \times 10^{-5}$ & $1.1 \times 10^{-4}$ \\
\hline Lead & $5.8 \times 10^{-8}$ & $5.9 \times 10^{-7}$ & $1.8 \times 10^{-8}$ & $1.9 \times 10^{-7}$ & $7.6 \times 10^{-8}$ & $7.8 \times 10^{-7}$ \\
\hline Cobalt & $7.9 \times 10^{-9}$ & $9.4 \times 10^{-8}$ & $2.5 \times 10^{-9}$ & $3.0 \times 10^{-8}$ & $1.0 \times 10^{-8}$ & $1.2 \times 10^{-7}$ \\
\hline $\mathrm{CR}_{\text {sum }}$ & $2.1 \times 10^{-6}$ & $1.4 \times 10^{-5}$ & $1.6 \times 10^{-5}$ & $1.0 \times 10^{-4}$ & $1.8 \times 10^{-5}$ & $1.2 \times 10^{-4}$ \\
\hline \multicolumn{7}{|c|}{ Novodvinsk } \\
\hline Nickel & $2.0 \times 10^{-6}$ & $1.0 \times 10^{-5}$ & $1.6 \times 10^{-5}$ & $8.1 \times 10^{-5}$ & $1.8 \times 10^{-5}$ & $9.2 \times 10^{-5}$ \\
\hline Lead & $6.7 \times 10^{-8}$ & $2.9 \times 10^{-7}$ & $2.1 \times 10^{-8}$ & $9.1 \times 10^{-8}$ & $8.8 \times 10^{-8}$ & $3.8 \times 10^{-7}$ \\
\hline Cobalt & $7.9 \times 10^{-9}$ & $7.9 \times 10^{-8}$ & $2.5 \times 10^{-9}$ & $2.5 \times 10^{-8}$ & $1.0 \times 10^{-8}$ & $1.0 \times 10^{-7}$ \\
\hline $\mathrm{CR}_{\text {sum }}$ & $2.1 \times 10^{-6}$ & $1.1 \times 10^{-5}$ & $1.6 \times 10^{-5}$ & $8.1 \times 10^{-5}$ & $1.8 \times 10^{-5}$ & $9.2 \times 10^{-5}$ \\
\hline
\end{tabular}

Considering median concentrations of the examined metals, in all three cities the greatest contribution into adverse effects produced on circulatory organs, blood system, nervous system, kidneys, and liver was made by manganese (48-99\%); by cadmium (39-60\%) and lead $(20-42 \%)$, on the digestive and reproductive systems; by cobalt (64-84\%), on skin; nickel $(15-65 \%)$ and mercury (33-86\%), on the immune system.

In Severodvinsk total individual carcinogenic risk for the overall population amounted to $9.1 \times 10^{-4}$ under exposure to median concentrations of carcinogens; to $2.3 \times 10^{-3}$ at 90 -th percentile. In Arkhangelsk and Novodvinsk total carcinogenic risks for the overall population were the same at median level and amounted to $1.8 \times 10^{-5}$; at 90 -th percentile, they amounted to $1.2 \times 10^{-4}$ and $9.2 \times 10^{-5}$ respectively (Table 3 ).

Total carcinogenic risk in Severodvinsk was 51 times higher at median level, and 2025 times higher at 90-th percentile level, than in Arkhangelsk and Novodvinsk. Oral introduction made the major contribution (69-70\%) into carcinogenic risks occurrence in the examined cities. The greatest contribution into summary total carcinogenic risk was made by nickel (from 91 to 99\%). Population carcinogenic risk taken over 70 years under exposure to carcinogens in soil amounted to 2.4 at median level in Severodvinsk; to 0.09 , in Arkhangelsk; to 0.001 , in Novodvinsk. There were 0.03 annual additional cases of malignant neoplasms among population in Severodvinsk caused by carcinogens in soils.

Conclusion. Soil in housing areas in Severodvinsk contains the highest concentrations of metals in comparison with other cities located in arctic zones of Arkhangelsk region. It is due to emissions from industrial enterprises dealing with shipbuilding and machine building.

Carcinogenic and non-carcinogenic risks under exposure to chemical contaminants in soil are higher in Severodvinsk than in two other examined cities; they are permissible when taken at median concentrations. Carcinogenic risk taken at 90-th percentile is higher than permissible values; it is subject 
to permanent control and requires developing a set of activities aimed at reducing soil contamination with chemicals. These activities should include improved production technologies that can ensure smaller emissions and discharges of adverse substances into the environment; new enterprises on wastes recycling and processing; construc- tion and reconstruction of sewage disposal plants; detection and lamination of contamination sources.

Funding. The research was not granted any financial support.

Conflict of interests. The authors declare there is no any conflict of interests.

\section{References}

1. Tafeeva E.A., Ivanov A.V., Titova A.A., Petrov I.V. Content of heavy metals and petroleum products in the soil on the territory of oil-producing areas of the Republic of Tatarstan. Gigiena i sanitariya, 2016, vol. 95, no. 10, pp. 939-941 (in Russian).

2. Deryabin A.N., Unguryanu T.N. Assessment of biological pollution of soil in the Arkhangelsk Region. Zdorov'e naseleniya i sreda obitaniya, 2017, vol. 292, no. 7, pp. 18-21(in Russian).

3. Vodyanova M.A., Kriatov I.A., Donerian L.G., Evseeva I.S., Ushakov D.I., Sbitnev A.V. Ecological hygienic assessment of soils quality in urban areas. Gigiena i sanitariya, 2016, vol. 95, no. 10, pp. 913-916 (in Russian).

4. Ivanov S.A., Dmitrieva O.F., Kulmakova N.I., Dimitriev Yu. O. Soil pollution from toxins of the Volga river shoreland in the area of Cheboksary hydropower station. Ekologiya cheloveka, 2016, no. 5, pp. 3-8 (in Russian).

5. Benhaddya M., Boukhelkhal A., Halis Y., Hadjel M. Human health risks associated with metals from urban soil and road dust in an oilfield area of Southeastern Algeria. Archives of Environmental Contamination and Toxicology, 2016, vol. 70, no. 3, pp. 556-571. DOI:10.1007/s00244-015-0244-6

6. Sardar K., Sadaf M., Muhammad S., Gang L. Urban park soil contamination by potentially harmful elements and human health risk in Peshawar City, Khyber Pakhtunkhwa, Pakistan. Journal of Geochemical Exploration, 2016, vol. 165, pp. 102-110. DOI: 10.1016/j.gexplo.2016.03.007

7. Tilekova Z.T., Tonkopii M.S., Tastanova B.E. Evaluation of soil pollution by heavy metals in Balkhash region. Fundamental'nye issledovaniya, 2015, no. 2, pp. 3723-3726 (in Russian).

8. Kolnet I.V., Studenikina E.M. Organization of monitoring of soil pollution level for risk assessment to child health. Nauchno-meditsinskii vestnik Tsentral'nogo Chernozem'ya, 2017, no. 70, pp. 100-105 (in Russian).

9. Kazantsev I.V., Matveeva T.B. Contents of heavy metals in the soil cover in the conditions of technogenesis. Samarskii nauchnyi vestnik, 2016, vol. 14, no. 1, pp. 34-37 (in Russian).

10. Sintsov A.V., Barmin A.N., Valov M.V. Dynamics of heavy metals in urboecosystems' soils. Geologiya, geografiya i global'naya energiya, 2014, vol. 55, no. 4, pp. 148-156 (in Russian).

11. Cai L.M., Xu Z.C., Qi J.Y., Feng Z.Z., Xiang T.S. Assessment of exposure to heavy metals and health risks among residents near Tonglushan mine in Hubei, China. Chemosphere, 2015, vol. 127, pp. 127-135. DOI: 10.1016/j.chemosphere.2015.01.027

12. Shcherbakov A.V., Shcherbakova V.N. Vliyanie na zdorov'e cheloveka zagryazneniya pochv. [Impacts exerted on human health by soil contamination]. Aktual'nye problem estestvenno-nauchnogo obrazovaniya, zashchity okruzhayushchei sredy i zdorov'ya cheloveka: materialy IV Mezhdunarodnoi ochnoi nauchno-prakticheskoi konferentsii. Orel, Izdatel'stvo Orlovskogo gosudarstvennogo universiteta im. I.S. Turgeneva Publ., 2016, vol. 4, no. 4, pp. 424-426 (in Russian).

13. Teplaya G.A. Heavy metals as a factor of environmental pollution (review). Astrakhanskii vestnik ekologicheskogo obrazovaniya, 2013, vol. 23, no. 1, pp. 182-192 (in Russian).

14. Sardar K., Hameed S., Afzal S., Fatima S., Shakoor M., Bharwana S., Tauqeer H. Heavy Metals Contamination and what are the Impacts on Living Organisms. Greener Journal of Environmental Management and Public Safety, 2013, vol. 2 no. 4, pp. 172-179.

15. Ermolaeva S.V., Lavrushina E.E., Kurgaeva A.V. Assessment of soils pollution by heavy metals at territories of Ulyanovsk oblast. Izvestiya Samarskogo nauchnogo tsentra Rossiiskoi akademii nauk, 2013, vol. 15, no. 3 (3), pp. 978-980 (in Russian). 
16. Nikolaeva A.D. Ekologicheskie aspekty zagryazneniya pochv tyazhelymi metallami [Ecological aspects related to soil contamination with heavy metals]. Tatishchevskie chteniya. Aktual'nye problemy nauki i praktiki: materialy XIV mezhdunarodnoi nauchno-prakticheskoi konferentsii. Tol'yatti, Volzhskii universitet imeni V.N. Tatishcheva, 2017, vol. 1, pp. 231-235 (in Russian).

17. Buzinov R.V., Kiku P.F., Unguryanu T.N., Yarygina M.V., Gudkov A.B. Ot Pomor'ya do Primor'ya: sotsial'no-gigienicheskie i ekologicheskie problem zdorov'ya naseleniya: monografiya [From the Pomorye to the Prymorye: social-hygienic and ecological issues related to human health: a monograph]. Arkhangelsk, Izdatelstvo Severnogo gosudarstvennogo meditsinskogo universiteta Publ., 2016, 397 p. (in Russian).

18. Krasnoshchekov Yu.N. Microelements in the soils of the central Khangay pseudo-taiga larch forests in Mongolia. Sbornik materialov Vserossiiskoi nauchnoi konferentsii s mezhdunarodnym uchastiem, posvyashchennoi 50-letiyu Instituta pochvovedeniya i agrokhimii Sibirskogo otdeleniya RAN. In: A.I. Syso ed. Tomsk, 2018, pp. 47-51(in Russian).

19. Unguryanu T.N., Novikov S.M. Approaches to assessing the health risk under exposure to chemicals with account of age peculiarities. Gigiena i sanitariya, 2012, vol. 91, no. 5, pp. 98-101 (in Russian).

20. Unguryanu T.N., Gudkov A.B., Nikanov A.N. Health risk assessment of soil contaminants for health of urban population. Profilakticheskaya i klinicheskaya meditsina, 2012, no. 1, pp. 101-105 (in Russian).

Deryabin A.N., Unguryanu T.N., Buzinov R.V. Population health risk caused by exposure to chemicals in soils. Health Risk Analysis, 2019, no. 3, pp. 18-25. DOI: 10.21668/health.risk/2019.3.02.eng

Received: 27.03.2019

Accepted: 26.07 .2019

Published: 30.09.2019 